\title{
In search of "hepatic factor:" Lack of evidence for ALK1 ligands BMP9 and BMP10
}

Teresa L. Capasso ${ }^{1}$, Sara M. Trucco², Morgan Hindes², Tristin Schwartze ${ }^{3}$, Jamie L. Bloch², Jacqueline Kreutzer², Stephen C. Cook $^{2,4}$, Cynthia S. Hinck ${ }^{3}$, Davide Treggiari $^{1,5}$, Brian Feingold ${ }^{2,6}$, Andrew P. Hinck ${ }^{3}$, Beth L. Roman ${ }^{1,7}$

${ }^{1}$ Department of Human Genetics, University of Pittsburgh Graduate School of Public Health, Pittsburgh, PA

${ }^{2}$ Department of Pediatrics, University of Pittsburgh, Pittsburgh, PA

${ }^{3}$ Department of Structural Biology, University of Pittsburgh, Pittsburgh, PA

${ }^{4}$ Congenital Heart Center, Spectrum Health Helen DeVos Children's Hospital, Grand Rapids, MI

${ }^{5}$ Cystic Fibrosis Center, Azienda Ospedaliera Universitaria Integrata, Verona, Italy

${ }^{6}$ Clinical and Translational Science, University of Pittsburgh, Pittsburgh, PA

${ }^{7}$ Heart, Lung, Blood and Vascular Medicine Institute, University of Pittsburgh, Pittsburgh, PA

Correspondence to:

Beth L. Roman, 412.624.7006 romanb@pitt.edu

Sara M. Trucco, 412.692.8763 sara.trucco@chp.edu 
medRxiv preprint doi: https://doi.org/10.1101/2020.07.09.20148320; this version posted July 11, 2020. The copyright holder for this preprint (which was not certified by peer review) is the author/funder, who has granted medRxiv a license to display the preprint in perpetuity.

It is made available under a CC-BY 4.0 International license .

\section{Abstract}

In children with single ventricle physiology, the Glenn procedure is performed to redirect venous return from the superior vena cava directly to the pulmonary arteries and route venous return from the inferior vena cava exclusively to the systemic circulation. Although this surgery successfully palliates the hemodynamic stress experienced by the single ventricle, patients frequently develop pulmonary arteriovenous malformations (PAVMs). Interestingly, PAVMs may regress upon rerouting of hepatic venous effluent to the pulmonary vasculature, suggesting the presence of a circulating "hepatic factor" that is required to prevent PAVMs. Here, we test the hypothesis that hepatic factor is bone morphogenetic protein 9 (BMP9) and/or BMP10. These circulating ligands are produced by the liver and activate endothelial endoglin (ENG)/ALK1 signaling, and mutations in ENG and ALK1 cause hereditary hemorrhagic telangiectasia, a genetic disease associated with AVM development. However, we found no within-subject variation in BMP9, BMP10, or BMP9/10 plasma concentrations when sampled from five cardiovascular sites, failing to support the idea that the Glenn would limit access of these ligands to the lung vasculature. Unexpectedly, however, we found a significant decrease in all three ligand concentrations in Glenn cases versus controls. Our findings suggest that BMP9/BMP10/ENG/ALK1 signaling may be decreased in the Glenn vasculature but fail to implicate these ligands as hepatic factor. 
medRxiv preprint doi: https://doi.org/10.1101/2020.07.09.20148320; this version posted July 11, 2020. The copyright holder for this preprint

(which was not certified by peer review) is the author/funder, who has granted medRxiv a license to display the preprint in perpetuity.

It is made available under a CC-BY 4.0 International license.

\section{$\underline{\text { Introduction }}$}

Considerable evidence suggests that the liver produces or modifies a circulating factor critical for preventing pulmonary arteriovenous malformations (PAVMs). In hepatopulmonary syndrome (HPS), liver dysfunction is associated with hypoxemia secondary to PAVMs, and PAVMs are reversed by liver transplantation (1). Additionally, portosystemic shunts that allow gut venous effluent to bypass the liver lead to PAVMs, which resolve when the shunt is closed (2). Further evidence comes from singleventricle patients who undergo a three-staged surgery to relieve hemodynamic burden on the heart and correct oxygen desaturation. The second-stage surgery, the bidirectional Glenn, directs passively draining venous return from the superior vena cava (SVC) to the pulmonary circulation, with venous return from the inferior vena cava (IVC) pumped to the systemic circulation. Although the Glenn effectively decreases ventricular hemodynamic stress, intrapulmonary arteriovenous shunting is pervasive, and up to $25 \%$ develop clinically significant hypoxemia secondary to diffuse PAVMs ( 3 , 4). While early theories of PAVM development focused on the absence of pulsatile flow or increased lower lobe perfusion (3), later evidence implicated the exclusion of a liverderived substance from the pulmonary vasculature. This "hepatic factor" was postulated based on correlation between laterality of PAVMs and laterality of exclusion of hepatic venous effluent (5), and its existence is strongly supported by evidence that the thirdstage Fontan procedure (completion of the total cavopulmonary anastomosis), which reroutes IVC flow to the lungs without restoring pulsatility, is strongly associated with PAVM regression (6). Despite the strong evidence for hepatic factor, its identity remains unknown. 
Approximately $80 \%$ of PAVMs are associated with hereditary hemorrhagic telangiectasia (HHT), a genetic disorder caused primarily by mutations in bone morphogenetic protein (BMP) receptors endoglin (ENG) and ALK1 (encoded by ACVRL1) (7). This pathway is active in lung endothelium and ligands include BMP9 and BMP10 homodimers and BMP9/10 heterodimer $(8,9)$. Both BMP9 and BMP10 are transcribed in hepatic stellate cells (9). Given the strong relationship between PAVMs and $\mathrm{HHT}$, the hepatic origins of BMP9 and BMP10, and evidence of decreased plasma BMP9 in HPS (10), we hypothesized that ALK1 ligands may be the hepatic factor required for PAVM prevention. We expect that hepatic factor is either labile or actively removed from circulation on first pass through the systemic circulation, making it unavailable to the lung vasculature in Glenn circulation. Accordingly, in normal circulation, we hypothesized that concentrations of ALK1 ligands would be higher in the right atrium and pulmonary artery compared to the SVC and infrahepatic IVC .

\section{Methods}

This study was approved by the University of Pittsburgh Institutional Review Board. Participants undergoing clinically-indicated cardiac catheterization were recruited between September 2015 and February 2017 and provided informed child assent and/or parental consent. Patients with bidirectional Glenn, prior to Fontan, were compared to two-ventricle controls. Excluded diagnoses among controls included single ventricle physiology, unrepaired complex congenital heart disease, and large shunt 
medRxiv preprint doi: https://doi.org/10.1101/2020.07.09.20148320; this version posted July 11, 2020. The copyright holder for this preprint

(which was not certified by peer review) is the author/funder, who has granted medRxiv a license to display the preprint in perpetuity.

It is made available under a CC-BY 4.0 International license.

lesions. Patients with liver disease, anemia (hemoglobin $<8 \mathrm{~g} / \mathrm{dL}$ ), cardiac surgery within 30 days, or transfusion within 48 hours were excluded from both cohorts.

We collected $1 \mathrm{ml}$ blood in $\mathrm{K}_{2}$ EDTA tubes from five sites: the right atrium, pulmonary artery, aorta, SVC, and infrahepatic IVC. We measured ligands in duplicate in $30 \mu \mathrm{L}$ of plasma via sandwich ELISAs (R\&D Systems, Minneapolis, USA) using DY3209 (BMP9), MAB2926 and BAF3956 (BMP10), and MAB2926 and BAF3209 (BMP9/10), using in-house generated recombinant proteins for the latter two standard curves. We fit data to a four parameter logistic curve and performed statistical analysis using GraphPad Prism (San Diego, USA). We ran all samples from an individual on a single plate, and the operator was blinded to sample identity. Sample volume limitations prevented us from assaying all ligands in every individual.

\section{$\underline{\text { Results }}$}

Diagnoses in 38 controls [mean age 5.8 years ( 4 months - 12.6 years); 21 males, 17 females] included: small shunt lesions (21), repaired forms of congenital heart disease with two-ventricle physiology (11), vascular stenosis (5), valvar obstructive lesions (2), and hypertrophic cardiomyopathy (1). Primary cardiac diagnoses in 9 Glenn cases [mean age 2.9 years (range 22 months to 5.1 years); 7 males, 2 females] included: variants of hypoplastic left heart syndrome (5); pulmonary atresia with intact ventricular septum (2); double outlet right ventricle with pulmonary atresia (1); and heterotaxy with right atrial isomerism (1). 
medRxiv preprint doi: https://doi.org/10.1101/2020.07.09.20148320; this version posted July 11, 2020. The copyright holder for this preprint

(which was not certified by peer review) is the author/funder, who has granted medRxiv a license to display the preprint in perpetuity.

It is made available under a CC-BY 4.0 International license.

BMPs are generated as proprotein dimers that are cleaved between the $\mathrm{N}$-terminal prodomains and C-terminal growth factor (GF) domains, releasing the disulfide-bonded GF dimer (GFD). In control plasma, we detected BMP9 GFD, BMP10 proprotein, and BMP9/10 GFD (Fig. 1), but not BMP10 GFD (DY2926, R\&D Systems; data not shown). However, we found no differences in plasma concentrations of any ALK1 ligand when comparing within-subject values across the right atrium, pulmonary artery, aorta, SVC, and IVC (Fig. 1). This result suggests that these ligands are neither particularly labile nor actively removed on first pass through the systemic or pulmonary circulation, failing to support the hypothesis that they represent the hepatic factor required to prevent PAVMs.

Evaluation of plasma from Glenn cases similarly revealed no significant differences in within-subject ligand concentrations across sampling sites (data not shown). However, after collapsing data across sites, comparison of grand means revealed significant decreases in plasma concentrations of all ligands in Glenn cases compared to controls (Fig. 2), and significance persisted after age-adjustment (multiple linear regression; BMP9, $P=0.04 ; \mathrm{BMP} 10, P=0.0002, \mathrm{BMP} 9 / 10, P=0.002)$. Although our sample set is underpowered, we saw no correlation between ligand concentration and PAVMs (Fig. 2).

\section{Discussion}

We found no within-subject differences in plasma concentrations of BMP9 GFD, BMP10 proprotein, or BMP9/10 GFD across different sampling sites, in agreement with a recent 
report regarding BMP9 GFD (11) and failing to support the idea that ALK1 ligands are the "hepatic factor" required to prevent PAVMs. However, it remains possible that liverderived BMP9 or BMP9/10 proproteins (not assayed) may exhibit site-dependent concentration differences, or that enzymes required to cleave proproteins are unavailable in the Glenn circulation. Surprisingly, we found that Glenn cases had significantly lower concentrations of all three ligands compared to controls.

Measurement of these ligands in additional Glenn cases and in Fontan cases will be required to determine the biological significance of this finding with respect to Glennassociated PAVMs.

\section{Funding}

University of Pittsburgh Heart, Lung, and Blood Vascular Medicine Institute and Vitalant Innovator Award, NIH R01HL133009, NIH R01HL136566, DOD WX18WH-17-1-0429. 
medRxiv preprint doi: https://doi.org/10.1101/2020.07.09.20148320; this version posted July 11, 2020. The copyright holder for this preprint

(which was not certified by peer review) is the author/funder, who has granted medRxiv a license to display the preprint in perpetuity.

It is made available under a CC-BY 4.0 International license.

\section{References}

1. Krowka MJ, Porayko MK, Plevak DJ, Pappas SC, Steers JL, Krom RA, Wiesner RH. Hepatopulmonary syndrome with progressive hypoxemia as an indication for liver transplantation: case reports and literature review. Mayo Clin Proc 1997; 72: 44-53.

2. Newman B, Feinstein JA, Cohen RA, Feingold B, Kreutzer J, Patel H, Chan FP. Congenital extrahepatic portosystemic shunt associated with heterotaxy and polysplenia. Pediatric radiology 2010; 40: 1222-1230.

3. Cloutier A, Ash JM, Smallhorn JF, Williams WG, Trusler GA, Rowe RD, Rabinovitch M. Abnormal distribution of pulmonary blood flow after the Glenn shunt or Fontan procedure: risk of development of arteriovenous fistulae. Circulation 1985; 72: 471-479.

4. Vettukattil JJ, Slavik Z, Lamb RK, Monro JL, Keeton BR, Tsang VT, Aldous AJ, Zivanovic A, Johns S, Lewington V, Salmon AP. Intrapulmonary arteriovenous shunting may be a universal phenomenon in patients with the superior cavopulmonary anastomosis: a radionuclide study. Heart 2000; 83: 425-428.

5. Srivastava D, Preminger T, Lock JE, Mandell V, Keane JF, Mayer JE, Jr., Kozakewich H, Spevak PJ. Hepatic venous blood and the development of pulmonary arteriovenous malformations in congenital heart disease. Circulation 1995; 92: 1217-1222.

6. Shah MJ, Rychik J, Fogel MA, Murphy JD, Jacobs ML. Pulmonary AV malformations after superior cavopulmonary connection: resolution after inclusion of hepatic veins in the pulmonary circulation. Ann Thorac Surg 1997; 63: 960-963.

7. Roman BL, Hinck AP. ALK1 signaling in development and disease: new paradigms. Cell Mol Life Sci 2017; 74: 4539-4560.

8. Mahmoud M, Borthwick GM, Hislop AA, Arthur HM. Endoglin and activin receptor-like-kinase 1 are co-expressed in the distal vessels of the lung: implications for two familial vascular dysplasias, HHT and PAH. Lab Invest 2009; 89: 15-25. 
medRxiv preprint doi: https://doi.org/10.1101/2020.07.09.20148320; this version posted July 11, 2020. The copyright holder for this preprint

(which was not certified by peer review) is the author/funder, who has granted medRxiv a license to display the preprint in perpetuity.

It is made available under a CC-BY 4.0 International license .

9. Tillet E, Ouarne M, Desroches-Castan A, Mallet C, Subileau M, Didier R, Lioutsko A, Belthier G, Feige JJ, Bailly S. A heterodimer formed by bone morphogenetic protein 9 (BMP9) and BMP10 provides most BMP biological activity in plasma. J Biol Chem 2018; 293: 10963-10974.

10. Rochon ER, Krowka MJ, Bartolome S, Heresi GA, Bull T, Roberts K, Hemnes A, Forde KA, Krok KL, Patel M, Lin G, McNeil M, Al-Naamani N, Roman BL, Yu PB, Fallon MB, Gladwin MT, Kawut SM, Pulmonary Vascular Complications of Liver Disease 2 Study G. BMP 9/10 in Pulmonary Vascular Complications of Liver Disease. Am J Respir Crit Care Med 2020.

11. Shirali AS, Lluri G, Guihard PJ, Conrad MB, Kim H, Pawlikowska L, Bostrom KI, IruelaArispe ML, Aboulhosn JA. Angiopoietin-2 predicts morbidity in adults with Fontan physiology. Scientific reports 2019; 9: 18328. 


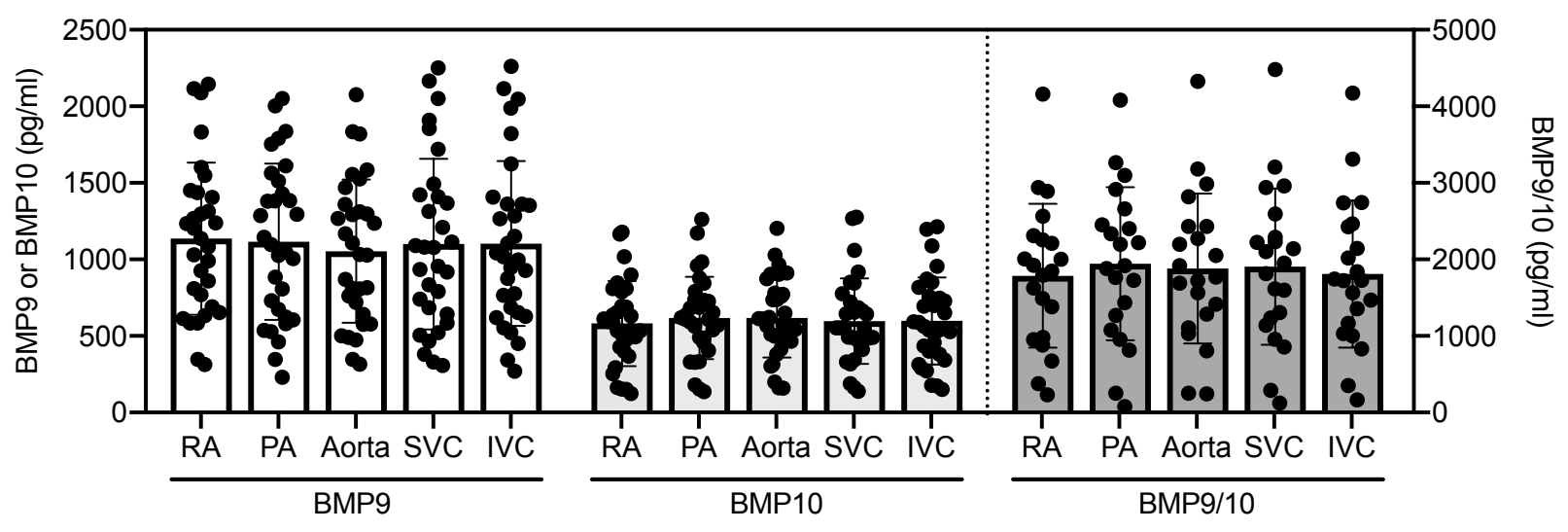

Figure 1. Plasma BMP9, BMP10, and BMP9/10 concentrations do not differ between pulmonary inflow and systemic venous circulation. Plasma from controls was sampled from the right atrium (RA), pulmonary artery (PA), aorta, SVC, and infrahepatic IVC and ligands quantified by sandwich ELISA. All values are GFD equivalents. Error bars, mean \pm SD. Not significant by repeated measures one-way ANOVA: BMP9, $N=31, P=0.13 ; \mathrm{BMP} 10, \mathrm{~N}=31, P=0.17 ; \mathrm{BMP9} / 10, \mathrm{~N}=21, P=0.21$. 


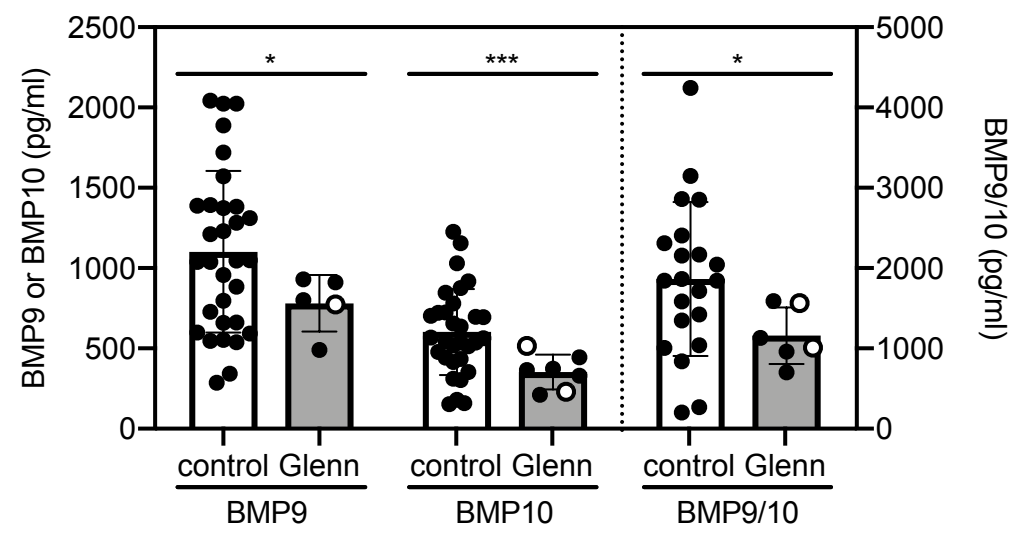

Figure 2. Plasma BMP9, BMP10, and BMP9/10 concentrations are lower in Glenn cases compared to controls. Within-patient data were averaged across all sampling sites (RA, PA, aorta, SVC, IVC) for controls and Glenn cases and evaluated by Welch's $t$-test. Error bars, mean \pm SD. BMP9: control, $\mathrm{N}=31$; Glenn, $\mathrm{N}=5 ; P=0.02$. BMP10: control, $\mathrm{N}=31$; Glenn, $\mathrm{N}=7 ; \mathrm{P}=0.0006$. BMP9/10: control, $\mathrm{N}=21$; Glenn, $\mathrm{N}=6 ; P=0.01$. Open circles indicate cases with PAVMs. 